\title{
IMPROVED DELINEATION OF INDIVIDUAL OUTLET GLACIER DRAINAGE BASINS FROM TANDEM-X ELEVATIONS AND SENTINEL-1 VELOCITIES
}

\author{
Lukas Krieger, Dana Floricioiu \\ German Aerospace Center (DLR), Remote Sensing Technology Institute (IMF) \\ Oberpfaffenhofen, Germany \\ Email: lukas.krieger@dlr.de; dana.floricioiu@dlr.de
}

\begin{abstract}
Individual drainage basins of ice sheets specify the glaciated area that is drained by a single outlet glacier. These catchments are needed to partition mass balance measurements to the single glacier level. Until now complete glacier inventories that contain annotated basin information are missing for the Earth's two ice sheets. Here we present delineations of all major outlet glacier catchments in Northeast Greenland that have been produced by a modified watershed algorithm using TanDEM-X elevations and Sentinel-1 velocity measurements. The approach shows the potential to generate a complete basin inventory for entire Greenland and Antarctica.
\end{abstract}

Index Terms - Ice Sheet, Glacier, Drainage Basin, Catchment, Ice Divide

\section{INTRODUCTION}

The increasing availability of new remote sensing data facilitates regular mass balance estimates of Greenland and Antarctica [1]. Altimetry, gravimetry and InSAR-based measurements have been reported on a large scale for the whole ice sheet or for major drainage regions [2, 3, 4]. There are also detailed mass balance studies on a single glacier level [5, 6] however a remaining challenge for these is to specify the geometric extent of the observed glacier systems. A standardised drainage basin delineation facilitates to compare such mass balance estimates.

Until now the ice sheets' major drainage sectors are separated along the ice divides that can be clearly identified in available DEMs of the ice sheets. This leads to an aggregation of several individual glacier basins into one large sector. Currently two catchment data sets are widely used, providing delineations based on altimetry measurements from ICESat data [7] and on the ERS/ICESat DEM combined with additional velocity information near the coast. [8]. While these sources provide excellent basin information for mass balance investigations on a large scale, there is also a need to partition mass

Funded by the Deutsche Forschungsgemeinschaft (DFG, FL 848/1-1); Variations of the ice sheet geometry, ice flow and mass distribution in Northeast Greenland in the context of oceanic and atmospheric interactions. balance measurements to the individual glacier level. The GLIMS database contains separate basins only for the periphery of the Greenland Ice Sheet and some additional glaciers in the southeast [9]. Previously, [6] has delineated basins for Nioghalvfjerdsfjorden (79North) and Zachariæ Isstrøm that were generated by combining ice velocity and DEM information and [10] showed that individual glacier basins can be delineated along the minima of a balance velocity field. Other authors report findings based on self assessed drainage basins that were derived from watershed analysis assuming surface parallel ice flow $[11,12]$. Still, a complete basin inventory for individual outlet glaciers is not readily available and detailed methodology for deriving these catchments is lacking.

In the following, we propose an approach to delineate individual drainage basins for single outlet glaciers with a modified watershed algorithm combining elevations from the TanDEM-X (TDM) global DEM and Sentinel-1 velocity measurements.

\section{DATA}

The used DEM is the TDM global DEM which was released in a freely available version at a posting of approx. $90 \mathrm{~m}$. It consist of averaged InSAR elevation measurements in the time between 2011 and 2014 [13] and has a vertical accuracy of $6.37 \mathrm{~m}$ (90\% linear error) over ice covered terrain [14]. For the present application in the modified watershed algorithm the DEM was smoothed with an average kernel of a width of 20 times the local ice thickness [15][16, Chapter 8.7.2].

As source of flow directions, ice surface velocity measurements produced within the Greenland Ice Sheet project of ESA's Climate Change Initiative (GrIS-cci) Programme have been selected. The velocities have been derived through offset tracking on Sentinel-1 backscattering amplitude images. The averaged east and north velocity components from the available time-series between 2014 - 2017 yield one complete velocity map posted on a grid of $250 \mathrm{~m}$ [17]. 


\section{MODIFIED WATERSHED ALGORITHM}

While a classical flood filling watershed algorithm uses the slope aspect angle of a DEM only [18], the modified version presented here utilises additional flow directions from ice surface velocity measurements. These are used in regions with fast ice flow where flow directions can be derived with high certainty. Here, flow disturbances can exist at glacier junctions or because of large bed rock features diverting the actual glacier flow from the direction of the steepest surface slope. Complementary, the DEM aspect angle is applied when the ice velocity is too slow for accurate direction estimates from speckle tracking.

Before processing, the DEM and east and north velocity components were resampled to a common grid of $100 \mathrm{~m}$ pixel size that inherently specifies the step size at which the modified watershed algorithm operates.

We initialise the modified watershed algorithm with seed regions placed on the outlet glacier termini of interest (Figure 1) and several other locations where ice drainage takes place [8]. Each seed region is assigned a unique label leading to a partition of the entire glaciated area.

The same way as a classical watershed algorithm [19] a priority queue of pixels is formed and sorted by minimum elevation. The entire glaciated area is processed by increasing elevation from the ice sheet margins to the interior [20]. Whenever a pixel with fast ice flow is encountered $\left(>20 \mathrm{~m} \mathrm{a}^{-1}\right)$ a streamline is calculated for this starting pixel where the upstream flow is followed according to [21] and neighbouring pixels are inserted into the priority queue as usual.

The threshold of $20 \mathrm{~m} \mathrm{a}^{-1}$ is found as the point of maximum correlation in an angle analysis of the flow directions and DEM aspect angles over the entire region of interest.

\subsection{Monte Carlo experiment with the modified water- shed algorithm}

To avoid that local errors in the DEM or in the ice velocity data set propagate to errors in the entire basin delineation a Monte Carlo experiment is performed by adding Gaussian noise with zero mean to the DEM $(\sigma=100 \mathrm{~m})$ and east and north velocity components $\left(\sigma=50 \mathrm{~m} \mathrm{a}^{-1}\right)$. After performing a number of runs $(\mathrm{N}=500)$ of the modified watershed algorithm with randomised initialisation, each pixel is assigned the label of maximal occurrence in all runs.

\section{RESULTS}

The Northeast Greenland region has been divided into drainage basins for each seed region that was used for initialising the modified watershed algorithm. Only 33 individual catchments for the largest, named outlet glaciers are shown and catchments for smaller unnamed glaciers are unclassified and left transparent in Figure 1. This reveals that almost the entire sector is drained through the named outlet glaciers and only $6.6 \%$ of the area drain elsewhere. Table 1 details the area, volume and other drainage basin statistics for the largest three glaciers in Northeast Greenland. 79North and Zachariæ Isstrøm show the greatest extent with areas of $109961 \mathrm{~km}^{2}$ and $99329 \mathrm{~km}^{2}$, respectively. Both belong to the Northeast Greenland Ice Stream (NEGIS). They drain a combined area of $12.19 \%$ of the ice sheet and hold a potential sea level rise of $1.2 \mathrm{~m}$. The third largest glacier is Daugaard-Jensen with an area of $51286 \mathrm{~km}^{2}$.

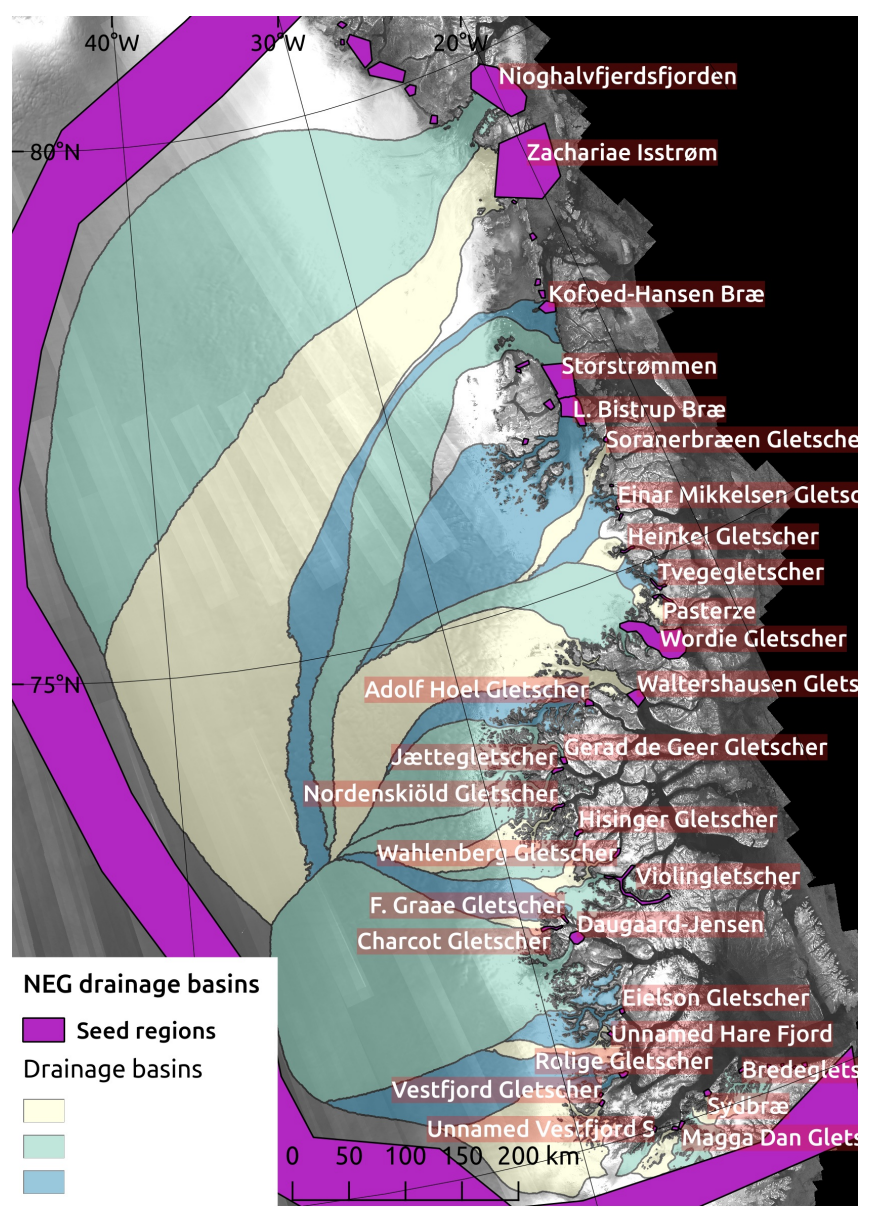

Fig. 1. Drainage basins for major outlet glaciers in Northeast Greenland. The seed regions used for the modified watershed algorithm are marked in purple. In the background a backscattering mosaic of the TDM global DEM mission.

\section{DISCUSSION \& CONCLUSION}

For the delineation of individual glacier drainage basins on the ice sheets a combination of ice flow direction from ice velocity measurements and ice flow along the steepest surface slope in the DEM has been shown. [22] and [6] already pro- 
Table 1. Drainage basin statistics of the largest 3 drainage basins in Northeast Greenland. The ice volume is calculated with the Bedmachine data set [15]. Percentages are given with respect to the total Greenland Ice Sheet area and volume [20].

\begin{tabular}{llllllll}
\hline Glacier name & $\begin{array}{l}\text { Drainage } \\
\text { area }\left[\mathrm{km}^{2}\right]\end{array}$ & $\begin{array}{l}\text { Area frac- } \\
\text { tion } \\
\text { GrIS [\%] }\end{array}$ & $\begin{array}{l}\text { Cumulative } \\
\text { drainage area } \\
{[\%]}\end{array}$ & $\begin{array}{l}\text { Ice volume } \\
{\left[\mathrm{km}^{3}\right]}\end{array}$ & $\begin{array}{l}\text { Fraction of } \\
\text { ice volume } \\
\text { of GrIS } \\
{[\%]}\end{array}$ & $\begin{array}{l}\text { Cumulative } \\
\text { ice } \\
{[\%]}\end{array}$ & $\begin{array}{l}\text { Sea } \\
\text { volume } \\
\text { equivalent } \\
{[\mathrm{m}]}\end{array}$ \\
\hline Nioghalvfjerdsfjorden (79North) & 109,961 & 6.41 & 6.41 & 232,842 & 7.91 & 7.91 & 0.59 \\
Zachariæ Isstrøm & 99,329 & 5.79 & 12.19 & 240,690 & 8.18 & 16.09 & 0.61 \\
Daugaard-Jensen & 51,286 & 2.99 & 15.18 & 118,004 & 4.01 & 20.10 & 0.30 \\
\hline
\end{tabular}

posed this combination taking into account that errors of the DEM and ice velocity data sets vary across the different areas of the ice sheet and complement each other.

The catchment area results given in Table 1 compare well to the sparse values found in the literature. From the supplementary material of [8] the drainage area of 79North is given with $103278 \mathrm{~km}^{2}$ and that of Zachariæ Isstrøm with $95103 \mathrm{~km}^{2}$. According to our reported findings the glacier catchments show area differences of $+6683 \mathrm{~km}^{2}(6 \%)$ and $+4226 \mathrm{~km}^{2}(4 \%)$ for 79North and Zachariæ Isstrøm, respectively. [6] report a $1.1 \mathrm{~m}$ sea level rise potential for 79North and Zachariæ Isstrøm, a value lower than our $1.2 \mathrm{~m}$. These discrepancies can arise for various reasons, including the choice of the DEM, the velocity data set or the used methodology.

Our method allows to generate individual drainage basin characteristics for all outlet glaciers in the entire sector. It shows the potential to delineate basins for entire Greenland and Antarctica where individual drainage basins have not been published previously.

\section{REFERENCES}

[1] A. Shepherd, E. R. Ivins, A. Geruo, et al., "A reconciled estimate of ice-sheet mass balance," Science, vol. 338, no. 6111, pp. 1183-1189, 2012.

[2] E. Rignot, I. Velicogna, M. R. van den Broeke, et al., "Acceleration of the contribution of the Greenland and Antarctic ice sheets to sea level rise," Geophys. Res. Lett., vol. 38, no. 5, 2011.

[3] A. Groh, H. Ewert, R. Rosenau, et al., "Mass, volume and velocity of the Antarctic Ice Sheet: present-day changes and error effects," Surv. Geophys., vol. 35, no. 6, pp. 1481-1505, 2014.

[4] M. van den Broeke, J. Bamber, J. Ettema, et al., "Partitioning recent Greenland mass loss," Science, vol. 326, no. 5955, pp. 984-986, 2009.

[5] I. M. Howat, Y. Ahn, I. Joughin, et al., "Mass balance of Greenland's three largest outlet glaciers, 2000-2010," Geophys. Res. Lett., vol. 38, no. 12, 2011.
[6] J. Mouginot, E. Rignot, B. Scheuchl, et al., "Fast retreat of Zachariæ Isstrøm, northeast Greenland," Science, vol. 350, no. 6266, pp. 1357-1361, 2015.

[7] H. J. Zwally, M. B. Giovinetto, M. A. Beckley, et al., "Antarctic and Greenland drainage systems, GSFC cryospheric sciences laboratory," Available at http://icesat4.gsfC.nasa.gov/cryo_ data/ant_grn_drainage_systems.php, 2012.

[8] E. Rignot and J. Mouginot, "Ice flow in Greenland for the international polar year 2008-2009," Geophys. Res. Lett., vol. 39, no. 11, 2012.

[9] GLIMS and NSIDC, "Global Land Ice Measurements from Space glacier database.," 2005, updated 2018, Compiled and made available by the international GLIMS community and the National Snow and Ice Data Center, Boulder CO, U.S.A.

[10] I. Joughin, M. Fahnestock, S. Ekholm, et al., "Balance velocities of the Greenland ice sheet," Geophys. Res. Lett., vol. 24, no. 23, pp. 3045-3048, 1997.

[11] D. Felikson, T. C. Bartholomaus, G. A. Catania, et al., "Inland thinning on the Greenland ice sheet controlled by outlet glacier geometry," Nat. Geosci., vol. 10, no. 5, pp. 366, 2017.

[12] B. Marzeion, A. Jarosch, and M. Hofer, "Past and future sea-level change from the surface mass balance of glaciers," The Cryosphere, vol. 6, no. 6, pp. 1295-1322, 2012.

[13] B. Wessel, A. Bertram, A. Gruber, et al., "A new highresolution elevation model of Greenland derived from TanDEM-X," ISPRS Ann. of Photogramm. Remote Sens. Spatial Inf. Sci., vol. 3, pp. 9-16, 2016.

[14] P. Rizzoli, M. Martone, C. Gonzalez, et al., "Generation and performance assessment of the global TanDEM-X digital elevation model," ISPRS J. Photogramm. Remote Sens., vol. 132, pp. 119-139, 2017. 
[15] M. Morlighem, C. N. Williams, E. Rignot, et al., "Bedmachine v3: Complete bed topography and ocean bathymetry mapping of Greenland from multibeam echo sounding combined with mass conservation," Geophys. Res. Lett., vol. 44, no. 21, 2017.

[16] W. S. B. Paterson, The physics of glaciers, Elsevier, 2016.

[17] T. Nagler, H. Rott, M. Hetzenecker, et al., "The Sentinel-1 mission: New opportunities for ice sheet observations," Remote Sensing, vol. 7, no. 7, pp. 93719389, 2015.

[18] S. Beucher et al., "The watershed transformation applied to image segmentation," SCANNING MICROSCOPY-SUPPLEMENT-, pp. 299-299, 1992.

[19] R. Barnes, C. Lehman, and D. Mulla, "Priority-flood: An optimal depression-filling and watershed-labeling algorithm for digital elevation models," Computers \& Geosciences, vol. 62, pp. 117-127, 2014.

[20] I. M. Howat, A. Negrete, and B. Smith, "The Greenland Ice Mapping Project (GIMP) land classification and surface elevation data sets," The Cryosphere, vol. 8, no. 4, pp. 1509-1518, 2014.

[21] B. Cabral and L. C. Leedom, "Imaging vector fields using line integral convolution," in Proceedings of the 20th annual conference on Computer graphics and interactive techniques. ACM, 1993, pp. 263-270.

[22] E. Rignot, G. Buscarlet, B. Csatho, et al., "Mass balance of the northeast sector of the Greenland ice sheet: a remote-sensing perspective," J. Glaciol., vol. 46, no. 153, pp. 265-273, 2000. 